\title{
The role of three-dimensional visualization in revision hip arthroplasty
}

\author{
A.N. Kovalenko, I.I. Shubniakov, A.A. Dzhavadov, S.S. Bilyk, M.A. Cherkasov, A.V. Ambrosenkov, \\ A.P. Antipov
}

Vreden National Medical Research Center of Traumatology and Orthopedics, Saint Petersburg, Russian Federation

\begin{abstract}
Introduction Preoperative assessment of the acetabular bone defect location and size is an important stage in the preparation for revision hip arthroplasty. It is generally recognized that radiographs are not sensitive enough to assess peri-implant osteolysis, and therefore difficulties arise in determining the true dimensions of acetabular defects and in choosing the optimal surgical tactics. Purpose To determine the effect of three-dimensional visualization of the pelvic bones in patients with significant acetabular defects on the evaluation of the defect and the choice of surgical tactics at the stage of planning operations. Materials and methods For our study, a questionnaire was compiled, in which the surgeon's experience in performing revision interventions in the hip joint was evaluated and it was proposed to consistently evaluate 20 clinical cases based on radiographs, and then on three-dimensional reconstruction. Each clinical case was asked to be evaluated for defect type according to the Paprosky classification, and also to choose one of the proposed options of surgical techniques. Results After comparing the data obtained by viewing the radiographs with the data obtained after evaluating the three-dimensional reconstruction of the defect, the Kappa consistency coefficient for the type of defect according to the Paprosky classification was 0.10 (95\% confidence interval $0.05-0.26$ ), and for the choice of surgical tactics was equal to 0.08 (95\% confidence interval 0.01-0.15). It indicates that surgeons changed their minds in a significant number of cases. Conclusion The results of the study show the need for additional studies, in particular three-dimensional visualization, as part of the preoperative planning of revision arthroplasty, especially in cases of complex acetabular defects.
\end{abstract}

Keywords: revision arthroplasty, hip joint, three-dimensional visualization

\section{INTRODUCTION}

The data of epidemiological studies indicate a steady growth in the number of revision hip arthroplasty (RHA) in the coming years [1-4] due to an increase in life expectancy and in the absolute number of primary THA in young patients $[5,6]$.

The most common cause of RHA, according to national registers, is aseptic loosening, which is accompanied by peri-implant osteolysis [7]. Pathogenetically, the process of peri-implant osteolysis is initiated and supported not only by mechanical factors but also by a cascade of biological reactions based on inflammatory process and leading to progressive loss of bone tissue [8]. Osteolysis accompanying aseptic loosening is often asymptomatic until pain is felt due to mobility in the implant-bone interface [9].

Revision interventions feature great complexity and are associated with a high risk of postoperative complications [10,11], resulting in repeated revisions. Therefore, surgeons in their practice face with complex bone defects in the acetabulum, requiring the search for new solutions at the planning and surgical treatment stages. The preoperative assessment of the location and size of bone defects in the acetabulum is an important stage in the preparation for revision surgery and determines the intraoperative tactics regarding the choice of the necessary implants and methods for bone defect management [12]. The location of the defect and its dimensions are not the only aspects that should be considered in preoperative planning. Ideally, surgeons should know the exact amount of bone loss in order to assess the need and possibility of using structural allo- and autografts, serial cups of large sizes, metal augments, support rings and cup-cage designs. Information on the quality of the peri-implant bone, integrity of reaming, osseointegration sites can also be used to assess the expected loss of bone tissue when removing an unstable acetabular component [13].

Various classifications have been proposed for defects in the acetabulum, [14-17] but the classification of W.G. Paprosky (18) published in 1994 is the most widely used in clinical practice. This classification defines the main patterns in the process of peri-implant osteolysis and is based on four radiological signs that characterize changes in various parts of the acetabulum [19].

The Paprosky classification is a useful tool in determining the acetabular defect type and the algorithm for subsequent surgical treatment. However, given its limited reliability and validity $[20,21]$ and the growing

Kovalenko A.N., Shubniakov I.I., Dzhavadov A.A., Bilyk S.S., Cherkasov M.A., Ambrosenkov A.V., Antipov A.P. The role of three-dimensional visualization in revision hip arthroplasty. Genij Ortopedii, 2020, vol. 26, no 3, pp. 364-369. DOI 10.18019/10284427-2020-26-3-364-369 
number of increasingly complex situations by performing RHA, there is a need for additional diagnostic options, which should include three-dimensional reconstruction of the pelvis based on CT scans [22].

To date, the available studies have not raised the issue of the significance and impact of three-dimensional reconstruction on preoperative planning and the choice of surgical tactics for revision arthroplasty.

Based on the foregoing, it seems reasonable to provide the surgeon with the most complete information about the area of surgical intervention, as well as to demonstrate the differences in the assessment of defects in the acetabulum and the choice of surgical tactics according to plain X-ray examination and three-dimensional reconstruction.

Purpose Determine the significance of performing three-dimensional reconstruction of the pelvic bones in patients with significant defects in the acetabulum at the stage of planning RHA operations and choosing the necessary implants for revision.

\section{MATERIALS AND METHODS}

To complete our study, a questionnaire was compiled that consists of questions of the introductory part to determine the experience of surgeons in performing RHA (Table 1) and the main part with 20 clinical examples before and after threedimensional reconstruction. It is available at http:// orthoopros.ru/opros-5.

In the first part of the questionnaire, the participants of the survey were asked to assess defects in the acetabulum in the X-rays which included three images: a panoramic radiograph of the pelvis and radiographs of the hip joint in direct and axial projections (Fig. 1).

Next, the same 20 examples were presented by three-dimensional reconstruction with the possibility of a circular vizualization (Fig. 2). The sequence of the demonstration of the cases was different from the sequence of radiographs and was random presentation.

Table 1

Questions of presentations

\begin{tabular}{|l|l|l|}
\hline$N^{\circ}$ & \multicolumn{1}{|c|}{ Question } & \multicolumn{1}{c|}{ Variant of answer } \\
\hline 1 & Name and surname & \multicolumn{1}{c|}{-} \\
\hline 2 & $\begin{array}{l}\text { Experience in hip } \\
\text { arthroplasty, years }\end{array}$ & $\begin{array}{l}\text { (1) less than 10; } \\
\text { (2) from 10 to 20; } \\
\text { (3) from 21 to 30; } \\
\text { (4) more than 30 }\end{array}$ \\
\hline 3 & $\begin{array}{l}\text { (1) District hospital; } \\
\text { (2) City hospital; } \\
\text { (3) Regional hospital; } \\
\text { institution }\end{array}$ & $\begin{array}{l}\text { (4) Federal medical centre; } \\
\text { (5) research institution } \\
\text { of traumatology and } \\
\text { orthopaedics }\end{array}$ \\
\hline 4 & $\begin{array}{l}\text { Number of primary } \\
\text { hip arthroplasties } \\
\text { performed per year }\end{array}$ & $\begin{array}{l}\text { (1) Fewer than10; } \\
\text { (2) from 10 to 30; } \\
\text { (3) from 31 to 51; } \\
\text { (4) from 51 to 100; } \\
\text { (5) More than 100 }\end{array}$ \\
\hline 5 & $\begin{array}{l}\text { (1) less than 10; } \\
\text { Number of revision } \\
\text { (2) from 10 to 30; } \\
\text { performed per year }\end{array}$ & $\begin{array}{l}\text { (3) from 31 дoto 51; } \\
\text { (4) from 51 to 100; } \\
\text { (5) More than 100 }\end{array}$ \\
\hline
\end{tabular}
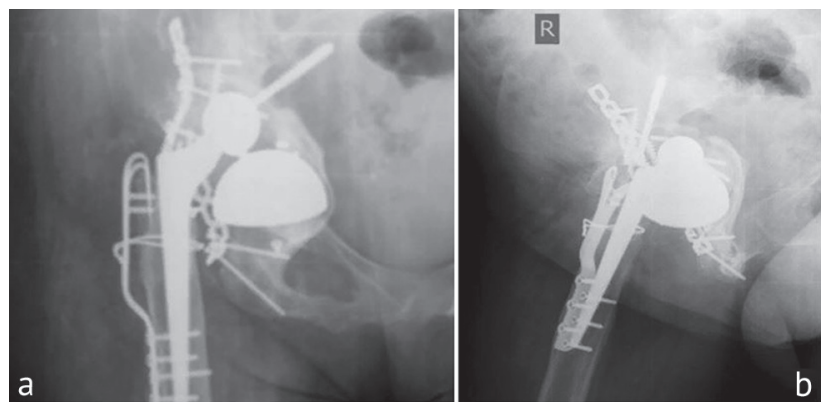

Fig. 1 Radiographs of a 44-year-old patient presented for evaluation in the questionnaire: $a$ - anteroposterior view; $b$ - axial projection
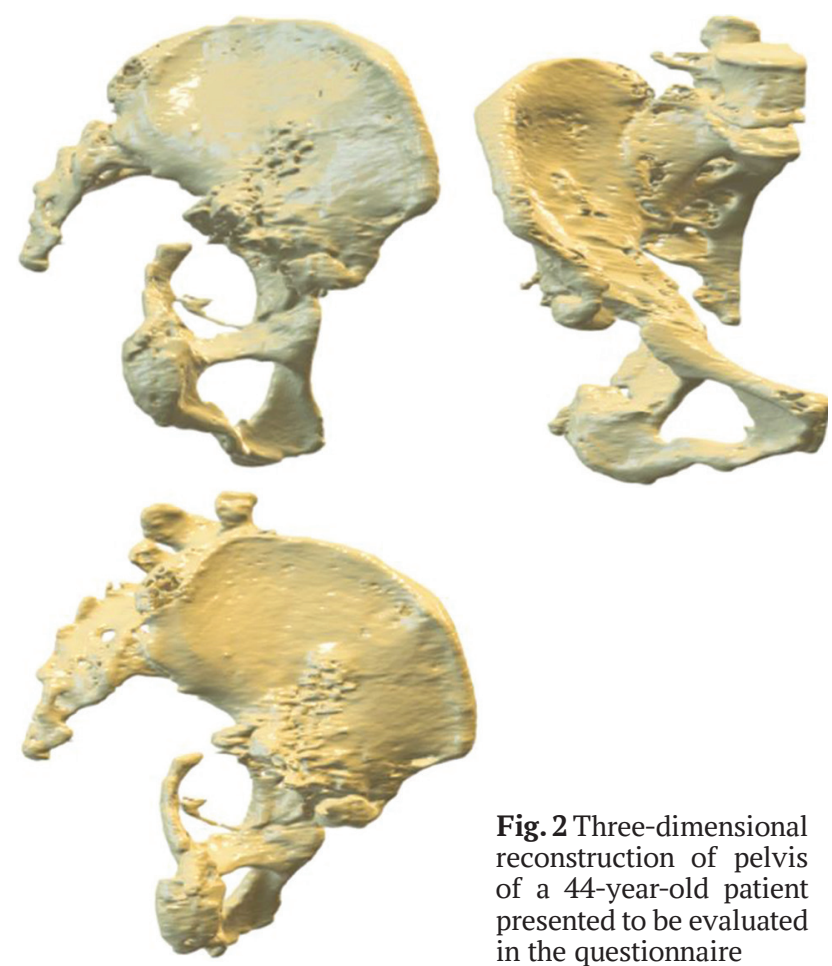

Fig. 2 Three-dimensional reconstruction of pelvis of a 44-year-old patient presented to be evaluated in the questionnaire

It was necessary to answer three questions on each case (Table 2) with the possibility of determining the type of defect according to the Paprosky classification, and also to choose one of the proposed surgical options. Next, surgeons' answers on each case were compared, and differences in the classification of defects and the choice of the method of surgical reconstruction of the defect area before and after the demonstration of 
three-dimensional reconstruction were found.

Statistical processing was performed in the IBM SPSS Statistics v.23.0.0.0; Kappa consistency coefficient was used to determine the consistency of surgeons in determining the defect type according to Paprosky and choosing surgical tactics (25).

Table 2

Questions for discussing radiographs and CT reconstructions

\begin{tabular}{|c|c|c|}
\hline № & Questions & Variants of answers \\
\hline 1 & $\begin{array}{l}\text { What type of defect according to } \\
\text { Paprosky? }\end{array}$ & $\begin{array}{l}\text { (1) I; } \\
\text { (2) IIA; } \\
\text { (3) IIB; } \\
\text { (4) IIC; } \\
\text { (5) IIIA; } \\
\text { (6) IIIB; } \\
\text { (7) Breach of pelvic ring integrity }\end{array}$ \\
\hline 2 & $\begin{array}{l}\text { What variant of surgical treatment } \\
\text { is optimal in this case? }\end{array}$ & $\begin{array}{l}\text { (1) hemispherical acetabular component: } \\
\text { a) standard hemispherical acetabular components; } \\
\text { б) многодырчатый hemispherical acetabular components; } \\
\text { в) extra-large hemispherical acetabular components (Jumbo cup); } \\
\text { (2) hemispherical acetabular component combined with: } \\
\text { a) sector augment; } \\
\text { b) butress; } \\
\text { в) antiprotrusion rings (Burch-Schneider ring, Mueller ring); } \\
\text { (3) Customized implant }\end{array}$ \\
\hline 3 & $\begin{array}{l}\text { What additional options would } \\
\text { you use? }\end{array}$ & $\begin{array}{l}\text { (1) impaction bone plasty with cemented component; } \\
\text { (2) bone chips plasty; } \\
\text { (3) bone plasty with structural graft; } \\
\text { (4) use of computer navigation; } \\
\text { (5) your own variant }\end{array}$ \\
\hline
\end{tabular}

\section{RESULTS}

Ten surgeons took part in the survey. Depending on their professional experience, they were divided into three groups: a) clinical residents; b) surgeons with experience from 10 to 50 revision hip arthroplasties per year; c) highly experienced surgeons performing from 51 to 100 operations of revision hip arthroplasties per year (Table 3).

Professional experience of surgeons

\begin{tabular}{|c|c|c|}
\hline Residents & $\begin{array}{c}\text { Experienced } \\
\text { surgeons }\end{array}$ & $\begin{array}{c}\text { Highly experienced } \\
\text { surgeons }\end{array}$ \\
\hline $\mathrm{n}=3$ & $\mathrm{n}=4$ & $\mathrm{n}=3$ \\
\hline
\end{tabular}

It was found that after defining the defect type according to the Paprosky classification, the number of matches for a plain X-ray image and three-dimensional reconstruction was from 10 to $45 \%$ (Fig. 3). Matches in the group of residents ranged from 20 to $35 \%$, in the group of experienced surgeons from 15 to $35 \%$, and in the group of highly experienced surgeons from 10 to $45 \%$. We also estimated the percentage of cases when surgeons tended to aggravate or simplify the defect type after examination of three-dimensional reconstructions. The Kappa consistency coefficient in the sequential assessment of an X-ray image and three-dimensional reconstruction by the same surgeon was 0.10
(95\% CI 0.05-0.26), which indicates a rather low consistency in determining the type of defect using different imaging methods.

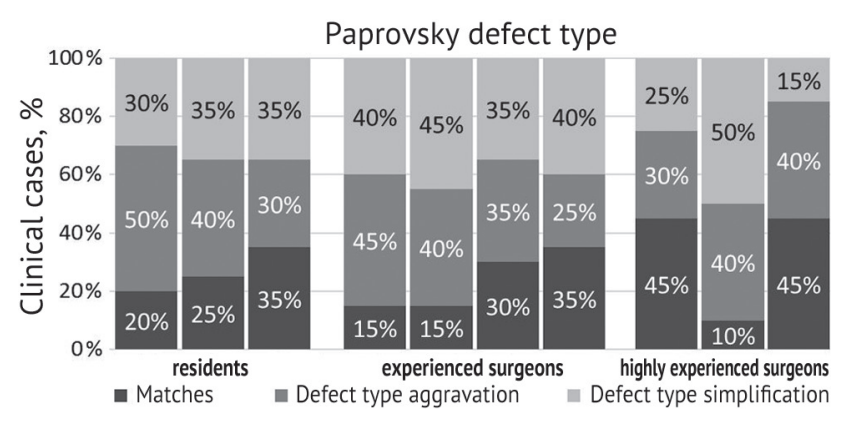

Fig. 3 A comparative analysis of differences in determining the type of defect according to Paprosky classification after surgeons have evaluated plain radiological images and three-dimensional pelvic reconstructions

In choosing the tactics of surgical treatment, the percentage of coincidences varied from 30 to $70 \%$ after examination of spatial reconstructions (Fig. 4). In the group of highly experienced surgeons, the percentage of matches was $45 \%$, in the group of residents from 30 to $50 \%$. The Kappa coefficient regarding the choice of surgical tactics was also low and amounted to 0.08 (95\% confidence interval 0.01-0.15).

After analyzing the choice of options for acetabular component fixation, the most experienced surgeons were more likely to change their mind about surgical 
techniques after examination of three-dimensional reconstructions with a tendency of increasing the stability by additional fixation of the acetabular component.
The lowest consistency (Kappa coefficient 0.03) was also found when surgeons chose additional options.

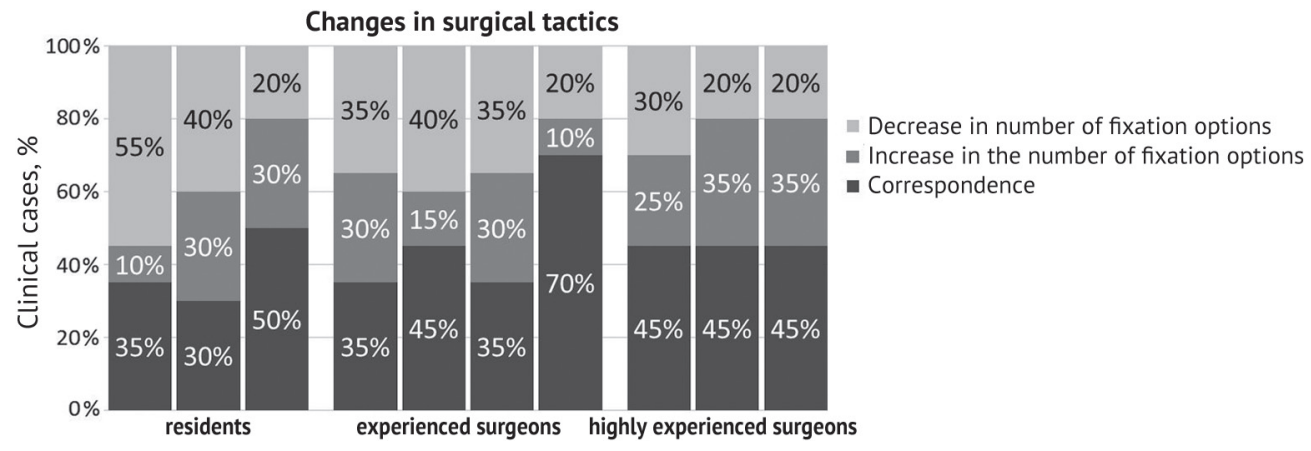

Fig. 4 Comparative analysis of the differences in the choice of surgical tactics after evaluation of plain radiological images and three-dimensional reconstruction of the pelvis

\section{DISCUSSION}

There are various opinions in the available literature regarding the use of three-dimensional technologies for planning in the orthopaedic practice. Brizzotto N. [23] describes the technique of spatial visualization of fractures as a logical development of preoperative planning which assists surgeons to significantly improve their understanding of damaged structures. Models of fracture sites were able to accurately reflect such features as articular surface fragment displacement and fragmentation of bone fragments. These nuances enabled to plan the length of the screws and the position of the reconstruction plates even at the preoperative stage. In contrast, Guy R.L. [24] and his team, discussing the importance of spatial reconstruction in acetabular fractures, came to the conclusion that it did not change the diagnosis but only slightly clarifies it. The additional fragments and cracks discovered by them according to the results of three-dimensional reconstruction did not have any practical significance. The authors emphasized the self-sufficiency of classical radiographs, although three-dimensional models were indicated as a good tool during the educational process and as a visual aid for young surgeons.

The need for preoperative 3D CT for planning was discussed in a study by P. Wu [25], where this technique found application in patients with acetabular dysplasia for accurate sizing of the acetabular component and screw positioning. The main conclusions of the work were the actual possibility of determining the size of the cup and the selection of the screw length using three-dimensional reconstruction in patients with dysplastic acetabulum [26].

Our study evaluated the difference in perception of the type of acetabulum defect on radiographs and three-dimensional reconstruction, as well as the effect of this difference on the choice of options for surgical tactics. The data obtained indicate a significant difference in the surgeon's perception of a specific clinical case while comparing two methods of imaging such defects. The Kappa consistency coefficient in determining the type of defect according to the Paprosky classification showed a very low value $(0.1)$, and even lower (0.08) for choosing a surgical tactic. In our opinion, it suggests that surgeons perceive and evaluate the defect differently in a significant number of cases, and also choose options for surgical tactics depending on the imaging method. Moreover, the difference in the assessment does not depend directly on the doctor's experience: the trained and most experienced surgeons changed their minds when determining the type of acetabular defect in 73 and $66 \%$ of clinical cases, and in relation to the chosen surgical tactics in 62 and $55 \%$ of clinical cases, respectively. When choosing additional options, respondents changed their opinion in $50 \%$ of clinical cases on average.

Statistically significant differences in assessing the types of defects in the acetabulum may be associated with limitations in the ability to visualize plain X-rays, especially in the presence of a massive implant, which ultimately affects the choice of surgical tactics. The standardized analysis of defects based on three-dimensional reconstruction has not gained wide popularity mainly due to the high complexity and higher radiation dose compared to conventional radiographic examination. Nevertheless, threedimensional reconstruction based on CT data is more informative in terms of the possibility of evaluating an object from various angles and representing a holistic model of a complex three-dimensional object.

The ultimate goal of revision arthroplasty in significant acetabular defects is stable long-term 
implant fixation. An improper planning of the surgical intervention may result in unexpected intraoperative findings that increase the duration of the operation, blood loss and anesthesia time, affecting the final result. In this regard, the modern approach to preoperative planning involves the use of the optimal number of tools that obtain much information about the defect, help the surgeon and, as a result, the patient, plan the treatment. Despite the data we obtained about a significant difference in the perception of radiographs and three-dimensional reconstruction and its effect on the choice of surgical tactics, we do not believe that these methods should be contrasted with each other and which one is better to choose. Three-dimensional reconstruction is able to examine the defect from all sides while traditional radiography gives an understanding of the overall quality of bone tissue, areas of reduction in its density, the possibility and necessity of restoring the anatomical centre of rotation, bringing the femur down, the need to exchange the femoral component and possible methods of removing existing implants.

Thus, the process of preoperative planning of revision arthroplasty in complex cases, in our opinion, should include not only X-ray and CT examinations, but also visualization using threedimensional reconstruction. These imaging methods are complementary in determining the shape and size of the acetabular defect and choosing the optimal surgical tactics. The use of 3D technologies in RHA is not limited to virtual three-dimensional visualization. It can be supplemented by subsequent 3D printing of the acetabular defect model, which enables to obtain the most complete information about the defect in comparison with a separate study of plain radiological images. This is applicable not only as a tool for planning and intraoperative assistance, but also to demonstrate to the patient the complexity of his/her particular case in comparison with normal anatomy and to deepen his/her understanding of the condition, objectify expectations from the operation and explain the nuances of postoperative rehabilitation treatment.

In conclusion, it should be noted that the results of the study indicate the importance of three-dimensional visualization of acetabular defects within the framework of preoperative preparation for revision arthroplasty, especially in cases of complex defects, and the feasibility of its use in regular practice.

\section{REFERENCES}

1. Kurtz S., Ong K., Lau E., Mowat F., Halpern M. Projections of primary and revision hip and knee arthroplasty in the United States from 2005 to 2030. J. Bone Joint Surg. Am., 2007, vol. 89, no. 4, pp. 780-785. DOI: 10.2106/JBJS.F.00222.

2. Patel A., Pavlou G., Mújica-Mota R.E., Toms A.D. The epidemiology of revision total knee and hip arthroplasty in England and Wales: a comparative analysis with projections for the United States. A study using the National Joint Registry dataset. J. Bone Joint Surg. Am., 2015, vol. 97-B, no. 8, pp. 1076-1081. DOI: 10.1302/0301-620X.97B8.35170.

3. Bozic K.J., Kurtz S.M., Lau E., Ong K., Vail T.P., Berry D.J. The epidemiology of revision total hip arthroplasty in the United States. J. Bone Joint Surg. Am., 2009, vol. 91, no. 1, pp. 128-133. DOI: 10.2106/jbjs.h.00155.

4. Kurtz S.M., Ong K.L., Schmier J., Zhao K., Mowat F., Lau E. Primary and revision arthroplasty surgery caseloads in the United States from 1990 to 2004. J. Arthroplasty, 2009, vol. 24, no. 2, pp. 195-203. DOI: 10.1016/J.ARTH.2007.11.015.

5. Tikhilov R.M., Shubniakov I.I., Kovalenko A.N., Totoev Z.A., Liu B., Bilyk S.S. Struktura rannikh revizii endoprotezirovaniia tazobedrennogo sustava [The structure of early revisions of the hip arthroplasty]. Travmatologiia i Ortopediia Rossii, 2014, no. 2 (72), pp. 5-13. (in Russian)

6. Bashinskaya B., Zimmerman R.M., Walcott B.P., Antoci V. Arthroplasty Utilization in the United States is Predicted by AgeSpecific Population Groups. ISRN Orthop., 2012, vol. 2012, pp. 1-8, 185938. DOI:10.5402/2012/185938.

7. Sadoghi P., Liebensteiner M., Agreiter M., Leithner A., Böhler N., Labek G. Revision surgery after total joint arthroplasty: a complication-based analysis using worldwide arthroplasty registers. J. Arthroplasty, 2013, vol. 28, no. 8, pp. $1329-1332$. DOI:10.1016/j.arth.2013.01.012.

8. Abu-Amer Y., Darwech I., Clohisyz J. Aseptic loosening of total joint replacements: mechanisms underlying osteolysis and potential therapies. Arthritis Res. Ther., 2007, vol. 9, no. Suppl. 1, pp. S6. DOI:10.1186/ar2170.

9. Chiang P.P., Burke D.W., Freiberg A.A., Rubash H.E. Osteolysis of the pelvis: evaluation and treatment. Clin. Orthop. Relat. Res., 2003, no. 417, pp. 164-174. DOI:10.1097/01.blo.0000096816.78689.e5.

10.Murylev V.Iu., Petrov N.V., Rukin Ia.A., Elizarov P.M., Kalashnik A.D. Revizionnoe endoprotezirovanie vertluzhnogo komponenta endoproteza tazobedrennogo sustava [Revision arthroplasty of the acetabular component of the hip implant]. Kafedra Travmatologii i Ortopedii, 2012, no. 1, pp. 20-25. (in Russian)

11.Badarudeen S., Shu A.C., Ong K.L., Baykal D., Lau E., Malkani A.L. Complications after revision total hip arthroplasty in the Medicare population. J. Arthroplasty, 2017, vol. 32, no. 6, pp. 1954-1958. DOI: 10.1016/j. arth.2017.01.037.

12.Korytkin A.A., Zakharova D.V., Novikova Ia.S., Gorbatov R.O., Kovaldov K.A., El Mudni Iu.M. Opyt primeneniia individualnykh trekhflantsevykh vertluzhnykh komponentov pri revizionnom endoprotezirovanii tazobedrennogo sustava [The experience of using three-flange acetabular components during revision arthroplasty of the hip]. Travmatologiia i Ortopediia Rossii, 2017, vol. 23, no. 4, pp. 101-111. (in Russian)

13.Kieser D.C., Ailabouni R., Kieser S.C.J., Wyatt M.C., Armour P.C., Coates M.H., Hooper G.J. The use of an Ossis custom 3D-printed triflanged acetabular implant for major bone loss: minimum 2-year follow-up. Hip Int., 2018, vol. 28, no. 6, pp. 668-674. DOI: $10.1177 / 1120700018760817$. 
14.Gross A.E., Allan D.G., Catre M., Garbuz D.S., Stockley I. Bone grafts in hip replacement surgery. The pelvic side. Orthop. Clin. North Am., 1993, vol. 24, no. 4, pp. 679-695.

15.Paprosky W.G., Perona P.G., Lawrence J.M. Acetabular defect classification and surgical reconstruction in revision arthroplasty. A 6-year follow-up evaluation. J. Arthroplasty, 1994, vol. 9, no. 1, pp. 33-44. DOI:10.1016/0883-5403(94)90135-x.

16.D'Antonio J.A., Capello W.N., Borden L.S., Bargar W.L., Bierbaum B.F., Boettcher W.G., Steinberg M.E., Stulberg S.D., Wedge J.H. Classification and management of acetabular abnormalities in total hip arthroplasty. Clin. Orthop. Relat. Res., 1989, no. 243, pp. 126-137. DOI:10.1097/00003086-198906000-00019.

17.Saleh K.J., Holtzman J., Gafni ASaleh L., Jaroszynski G., Wong P., Woodgate I., Davis A., Gross A.E. Development, test reliability and validation of a classification for revision hip arthroplasty. J. Orthop. Res., 2001, vol. 19, no. 1, pp. 50-56. DOI:10.1016/S07360266(00)00021-8.

18.Parry M.C., Whitehouse M.R., Mehendale S.A., Smith L.K., Webb J.C., Spencer R.F., Blom A. A comparison of the validity and reliability of established bone stock loss classification systems and the proposal of a novel classification system. Hip Int., 2010, vol. 20, no. 1, pp. 50-55. DOI:10.1177/112070001002000108.

19.Sporer S.M. How to do a revision total hip arthroplasty: revision of the acetabulum. J. Bone Joint Surg. Am., 2011, vol. 93, no. 14, pp. 1359-1366. DOI:10.2106/JBJS.9314icl.

20.Yu R., Hofstaetter J.G., Sullivan T., Costi K., Howie D.W., Solomon L.B. Validity and reliability of the Paprosky Acetabular Defect Classification. Clin. Orthop. Relat. Res., 2013, vol. 471, no. 7, pp. 2259-2265. DOI:10.1007/s11999-013-2844-7.

21.Tikhilov R.M., Shubniakov I.I., Denisov A.O. Klassifikatsii defektov vertluzhnoi vpadiny: daiut li oni obektivnuiu kartinu slozhnosti revizionnogo endoprotezirovaniia tazobedrennogo sustava? (Kriticheskii obzor literatury i sobstvennykh nabliudenii) [Classifications of acetabular defects: Do they give an objective picture of the complexity of the hip revision arthroplasty? (Critical review of the literature and own observations)]. Travmatologiia i Ortopediia Rossii, 2019, vol. 25, no. 1, pp. 122-141. (in Russian)

22.Kavalerskiy G.M., Murylev V.Y., Rukin Y.A., Elizarov P.M., Lychagin A.V., Tselisheva E.Y. Three-dimensional models in planning of revision hip arthroplasty with complex acetabular defects. Indian J. Orthop., 2018, vol. 52, no. 6, pp. 625-630. DOI: 10.4103/ ortho.IJOrtho_556_16.

23.Bizzotto N., Sandri A., Regis D., Romani D., Tami I., Magnan B. Three-Dimensional Printing of Bone Fractures: A New Tangible Realistic Way for Preoperative Planning and Education. Surg. Innov., 2015, vol. 22, no. 5, pp. 548-551. DOI: $10.1177 / 1553350614547773$.

24.Guy R.L., Butler-Manuel P.A., Holder P., Brueton R.N. The role of 3D CT in the assessment of acetabular fractures. Br. J. Radiol., 1992, vol. 65, no. 773, pp. 384-389. DOI: 10.1259/0007-1285-65-773-384.

25.Wu P., Liu Q., Fu M., Zhang Z., He S., Liao W., Kang Y. Value of Computed Tomography-Based Three-Dimensional Pre-operative Planning in Cup Placement in Total Hip Arthroplasty With Dysplastic Acetabulum. J. Invest. Surg., 2019, vol. 32, no. 7, pp. 607613. DOI: $10.1080 / 08941939.2018 .1444828$.

26.Horas K., Arnholdt J., Steinert A.F., Hoberg M., Rudert M., Holzapfel B.M. Acetabular defect classification in times of 3D imaging and patient-specific treatment protocols. Orthopäde, 2017, vol. 46, no. 2, pp. 168-178. DOI: 10.1007/s00132-016-3378-y.

Received: 09.01.2020

\section{Information about the authors:}

1. Anton N. Kovalenko, M.D., Ph.D., Vreden National Medical Research Center of Traumatology and Orthopedics, Saint Petersburg, Russian Federation, Email: tonnchik@ya.ru

2. Igor I. Shubniakov, M.D., Ph.D., Vreden National Medical Research Center of Traumatology and Orthopedics, Saint Petersburg, Russian Federation, Email: shubnyakov@mail.ru

3. Alisagib A. Dzhavadov, M.D., Vreden National Medical Research Center of Traumatology and Orthopedics, Saint Petersburg, Russian Federation, Email: alisagib.dzhavadov@mail.ru

4. Stanislav S. Bilyk, M.D.,

Vreden National Medical Research Center of Traumatology and Orthopedics, Saint Petersburg, Russian Federation, Email: bss0413@gmail.com

5. Magomed A. Cherkasov, M.D., Ph.D.,

Vreden National Medical Research Center of Traumatology and Orthopedics, Saint Petersburg, Russian Federation, Email: dr.medik@gmail.com

6. Andrei V. Ambrosenkov, M.D., Ph.D.,

Vreden National Medical Research Center of Traumatology and Orthopedics, Saint Petersburg, Russian Federation, Email: ortopedus09@gmail.com

7. Aleksandr P. Antipov, M.D.,

Vreden National Medical Research Center of Traumatology and Orthopedics, Saint Petersburg, Russian Federation, Email: a.p.antipov@ya.ru 